\title{
Hornification-its origin and interpretation in wood pulps
}

\author{
J.M.B. Fernandes Diniz, M.H. Gil, J.A.A.M. Castro
}

Abstract Although perfectly diagnosed in terms of the occurrence of physical changes, the hornification phenomenon, in its origin, has frequently been associated with the formation of irreversible or partially reversible hydrogen bonding in wood pulps or paper upon drying or water removal. Its characterisation has therefore been confusing and unsatisfactory. The authors propose that a sufficiently varied source of experimental data already exists to show that hornification is only a particular case of lactone bridge formation in lignocellulosic materials.

\section{Introduction}

The term "hornification" is a technical term used in wood pulp and paper research literature that refers to the stiffening of the polymer structure that takes place in lignocellulosic materials upon drying or water removal. When wood pulp fibres are dried, the internal fibre volume shrinks, because of structural changes in wood pulp fibres. If fibres are resuspended in water, the original water-swollen state is not regained (Minor 1994). The effect of hornification may be identified in those physical paper or wood pulp properties that are related to hydration or swelling, such as burst or tensile properties. Repeated recycles showed progressive variations in these properties for several cycles (Howard 1990). This concept, which was introduced by G. Jayme in 1944, was originally expressed by the German word "Verhornung", initially translated into English as "cornification", and later changed to "hornification" (Minor 1994). Jayme introduced the water retention value (WRV) measurement by centrifugation and defined irreversible hornification as a decrease in WRV, expressed in percentage of the original value (Jayme 1944). The decrease in WRV was found to correlate in multiple recycling very well with fibre thickness as measured from electron microscopic images, whereas no change in fibre width was detected after multiple fibre drying (Bawden and Kibblewhite 1995; Weise and Paulapuro 1996).

J.M.B. Fernandes Diniz ( $₫)$, M.H. Gil, J.A.A.M. Castro Departamento de Engenharia Química, Universidade de Coimbra, 3030-290 Coimbra, Portugal E-mail: jmfdinis@ci.uc.pt

Fax: +351-239-798703 
Further research showed that the process of drying of fibres causes a significant loss of large pores (Stone and Scallan 1966, 1968; Stone et al. 1968; Ehrnrooth 1984) and a reduction of surface area (Klungness and Caufield 1982; Krässig 1984).

Wet pressing has also been found to produce hornification (Robertson 1964; Maloney et al. 1997).

\section{Early mechanism characterisation}

Following some early reported findings (Jayme 1943; Frey-Wyssling 1951), the first description of the hornification mechanism was put forward in the 1950s (Jayme and Hunger 1956, 1957). In this theoretical framework, wet fibrils are envisaged as being brought into contact as a drying process proceeds (Jayme and Hunger 1956, 1957). The polysaccharide chains of cellulose are packed tighter with the removal of water upon drying (Jayme 1943), and microfibrils were observed to join in flat ribbons, in the dry state, as a result of tight packing (FreyWyssling 1951). The drying process would progressively close the capillary voids, which might not be completely reopened by newly intruding water (Jayme 1943). As a consequence, the irreversible hornified cell wall was believed to be less swollen and less flexible compared to the state before drying. When remoistered some surfaces remain coalescent, thus reducing the fibre surface accessed by water.

This phenomenon was described as essentially a feature of low-yield wood pulps (Jayme and Hunger 1956) once lignified pulps, such as mechanical pulps do not hornify to the extent that chemical pulps do (Jayme and Hunger 1957; Laivins and Scallan1993). In this context, hornification has thus been described as an increase in the degree of crosslinking within the fibre microstructure. Crosslinking was viewed as an irreversible (Lindström 1986) or partially irreversible (Laivins and Scallan 1993) connection of interfibril hydrogen bonding.

\section{Alternative mechanism characterisation}

The first contribution to an alternative interpretation of hornification was put forward in the 1960s by the proposal that thermal crosslinking takes place through the formation of esters (Ruffini 1966; Back 1967). It is known that a hydroxycarboxylic acid can undergo intramolecular esterification to yield a cyclic ester, called a lactone (Streitwieser and Heathcock 1989). The recognition of the presence of lactones in cellulosic materials can be traced to the early 1950s (Stakheeva-Kaverzneva and Salova 1951). In the 1960s the formation of lactones in cellulosic materials induced by fairly acidic media $(\mathrm{pH} \leq 2)$ (Samuelson and Törnell 1961; Wilson 1966; Slavik and Kucerova 1967) or by drying (Ruffini 1966; Slavik and Kucerova 1967, 1969) was reported. The lactone presence was qualitatively detected through the pink colour originated in the hydroxylamine-ferric chloride test (Stakheeva-Kaverzneva and Salova 1953) in hornified pulps but not detected in never-dried pulps (Ruffini 1966). The quantitative determination of lactones was performed colorimetrically (Slavik and Kucerova 1967, 1969) or through the variation of the carboxylic acid content (Ruffini 1966).

\section{Reversing hornification}

The irreversible character of hornification was a feature of the original description by G. Jayme (Jayme 1944; Weise 1998); it is still adopted by recent authors (Oksanen et al. 1997; Kato and Cameron 1999). Later experimentation showed that the swelling capacity of hornified fibres can be partly restored (Laivins and 
Scallan 1993; Klungness and Caufield 1982), and hornification reduced by beating (Brecht and Globig 1954; Kitayama et al. 1983), by the addition of bulking agents, like sucrose or glycerol adsorbed by the polymeric structure (Higgins and McKenzie 1963) or by insertion of spacer groups through derivatisation (Gruber and Weigert 1998).

A hornification reversion of $55 \%$ by alkali cooking has already been reported (Weise et al. 1998) and a US patent was issued on a process that was claimed to prevent hornification (Yasnovsky and MacDonald 1983). Heating the suspension of pulp under 120 psi of saturated steam at $\mathrm{pH}=8.1$ improved the subsequent reactivity of the pulp, and the patent authors proposed that the reason for the improvement was an inhibition of hornification.

\section{Discussion}

The readiness of hydrolization of lactones by dilute alkaline solutions in oxycelluloses has been long recognized (Kaverzneva et al. 1952; Samuelson and Wennerblom 1955; Slavik et al. 1967). The prevention of lactone formation in lignocellulosic materials was also proposed by the use of fairly alkaline solutions (Stakheva-Kaverzneva and Salova 1953) or lightly alkaline solutions of $\mathrm{pH}=8$ (Samuelson and Törnell 1961; Wilson 1966) to be taken into account in alkalimetric studies of wood pulps (Fernandes Diniz and Pethybridge 1995). Because of the existence of a Donnan equilibrium (Fernandes Diniz 1996), the $\mathrm{pH}$ of an external solution does not equal that of the internal pores of lignocellulosic materials (Scallan et al. 1989). Therefore, either a multiple cyclic exposure to fresh alkaline solutions of $\mathrm{pH} \geq 8$ or an external pressure sufficient to overcome the osmotic pressure between the external solution and the pore solution is capable of a total reversal of the hornification process. The latter condition is actually proposed in US patent 4,385,172 (Yasnovsky and MacDonald 1983).

The carboxyl groups contained in the wood pulp have been shown to have a major influence on the hornification of kraft fibres. When in their hydrogen or acidic form, they promote more hornification (Lindström and Carlsson 1982) in such a way that the degree of hornification increases with the growing number of carboxyl groups (Rácz and Borsa 1997). Conversely, a drying process that promotes hornification generates a drop in carboxylic acid content in pulps (Ruffini 1966). It was also shown that the velocity of crosslinking for a mechanical pulp during heat treatment increased with a periodate oxidation, which produced dialdehyde groups and decreased with the reduction of the mechanical pulp with sodium borohydride. Finally, the activation energy involved in the crosslinking process associated with hornification has been calculated and estimated between 80 and $130 \mathrm{~kJ} \mathrm{~mol}^{-1}$ (Back 1967), a value very much higher than hydrogen bonding, typically between 10 and $40 \mathrm{~kJ} \mathrm{~mol}^{-1}$ (Israelachvili 1991).

\section{Conclusions}

Although perfectly diagnosed in terms of the occurrence of physical changes, the hornification phenomenon, in its origin, has frequently been associated with the formation of irreversible or partially irreversible hydrogen bonding in wood pulps or paper upon drying or water removal (Smook 1990), thus overlooking research findings published in the 1950s and 1960s. The chemical description of hornification based on hydrogen bond crosslinking raises a few questions. One finds puzzling that certain polymeric intramolecular hydrogen bonds may be broken by water molecules, whereas some other hydrogen bonds cannot. 
In relation to thermochemistry and chemical bond theory, it is hard to envision this description of hornification as a coherent body of theory.

The fact that the prevention or reduction of hornification is attained by alkaline solutions and sodium borohydride, which are known to produce the cleavage of hemiacetal bonds (lactone bridges) in low polymer carbohydrates, and that both the hydroxyl and carboxyl groups play a significant role in the degree of hornification clearly suggest the ester linkage crosslinking nature of hornification. Furthermore, the esterification process of interlocking lignocellulosic chains also explains the increase in strength properties and loss of hygroscopicity acquired after a treatment with monochloroacetic acid for unbeaten pulps (Ruffini 1966). Therefore the authors conclude that a sufficiently varied source of experimental data already exists to show that hornification is only a particular case of lactone bridge formation in lignocellulosic materials.

In this perspective, water completely breaks hydrogen bonds in the amorphous part of the lignocellulose material, especially between fibres. Conversely, the removal of water may bring the solid material in close proximity and regenerate hydrogen bonding formation. Part of the existent carboxylic acid groups in the lignocellulosic structure will interact with hydroxyl groups in neighbouring polymeric chains and establish covalent lactone bridges. These lactone bridges will further condition the physical properties of the polymeric material such as a swelling decrease and an increase in wet strength parameters (wet breaking load, wet stiffness or wet modulus of elasticity). This covalent crosslinking is not broken by water molecules and will only disappear under the specific chemical conditions that reverse the lactone formation.

\section{References}

Back EL (1967) Thermal auto-crosslinking in cellulose material. Pulp Pap Mag Can 68:T165-T171

Bawden AD, Kibblewhite RP (1995) Effects of multiple drying treatments on kraft fibre walls. In: Third research forum on recycling. CPPA, Vancouver, pp 171-177

Brecht W, Globig C (1954) Untersuchung eines gebleichten Strohzellstoffes auf seine papiertechnologischen Eigenschaften. Wochenbl Papierfabr 82:807-813

Ehrnrooth EML (1984) The swelling of dried and never-dried acid chlorite delignified fibers. Svensk Papperstidn 87:R74-R77

Fernandes Diniz JMB (1996) Application of chemical equilibrium to wood pulps. Holzforschung 50:429-433

Fernandes Diniz JMB, Pethybridge AD (1995) Interfering lactone formation in alkalimetric studies of paper woodpulps. Holzforschung 49:81-83

Frey-Wyssling A (1951) Über verbänderte Cellulosemikrofibrillen in Zellwänden. Holz als Rohund Werkstoff 9:333-334

Gruber E, Weigert J (1998) Chemische Modifizierung von Zellstoffen zur Verminderung ihrer Verhornungsneigung. Papier 52:V20-V26

Higgins HG, McKenzie AW (1963) The structure and properties of paper. XIV. Effects of drying on cellulose fibres and the problem of maintaining pulp strength. Appita J 16:145-161

Howard RC (1990) The effects of recycling on paper quality. J Pulp Pap Sci 16:J143-J149

Israelachvili JN (1991) Intermolecular and surface forces, 2nd edn. Academic, San Diego, pp 123125

Jayme G (1943) Über die Reaktionsfähigkeit von Zellstoffen. Cellulosechemie 21:73-86

Jayme G (1944) Mikro-Quellungsmessungen an Zellstoffen. Wochenbl Papierfabr 6:187-194

Jayme G, Hunger G (1956) Verhornungserscheinungen an Cellulosefaserstrukturen in elektroneoptischer Sicht. Monatshefte für Chemie 87:8-23

Jayme G, Hunger G (1957) The rearrangement of microfibrils in dried cellulose and the implication of this structure alteration on pulp properties. In: Bolam F (ed) Fundamentals of papermaking fibres. BPBMA, Cambridge, pp 263-270

Kato KL, Cameron RE (1999) A review of the relationship between thermally-accelerated ageing of paper and hornification. Cellulose 6:23-40 
Kaverzneva ED, Ivanov VI, Salova AS (1952) Chemical transformations of the macromolecule of cellulose under the action of oxidizing agents. VI. The presence in oxycelluloses of the groupings of carbonic esters and their effect on the determination of uronic carboxylic groups. Izvest Akad Nauk SSSR, Otdel Khim Nauk, pp 185-189

Kitayama T, Okayama T, Oye R (1983) Changes of chemical pulp fibres during recycling. In: International symposium on wood and pulping chemistry, vol 3. Japanese TAPPI, Tsukuba, pp 118-123

Klungness JH, Caufield DF (1982) Mechanisms affecting fiber bonding during drying and aging of pulps. TAPPI J 65:94-97

Krässig H (1984) Struktur und Reaktivität von Cellulosefasern. Papier 38:571-582

Laivins GV, Scallan AM (1993) The mechanism of hornification of wood pulps. In: Baker CF (ed) Products of papermaking. Trans 10th fundamental research symposium. Pira International, Oxford, pp 1235-1260

Lindström T (1986) The porous lamellar structure of the cell wall. In: Bristow JA, Kolseth P (eds) Paper, structure and properties. Marcel Dekker, New York, pp 99-109

Lindström T, Carlsson G (1982) The effect of carboxyl groups and their ionic form during drying on the hornification of cellulose fibers. Svensk Papperstidn 85:R146-R151

Maloney TC, Li TQ, Weise U, Paulapuro H (1997) Intra- and inter-fibre pore closure in wet pressing. Appita J 50:301-306

Minor JL (1994) Hornification-its origin and meaning. Progr Pap Recycling 3:93-95

Oksanen T, Buchert J, Viikari L (1997) The role of hemicelluloses in the hornification of bleached kraft pulps. Holzforschung 51:355-360

Rácz I, Borsa J (1997) Swelling of carboxymethylated cellulose fibres. Cellulose 4:293-303

Robertson AA (1964) Some observations on the effects of drying papermaking fibres. Pulp Pap Mag Can 65:T161-T168

Ruffini G (1966) Improvement in bonding of wood pulps by the presence of acidic groups. Svensk Papperstidn 69:72-76

Samuelson O, Törnell B (1961) Influence of lactones upon the determination of carboxyl groups in cellulose. Svensk Papperstidn 64:198-203

Samuelson O, Wennerblom A (1955) Determination of carboxyl groups in cellulose. Svensk Papperstidn 58:713-716

Scallan AM, Katz S, Argyropoulos DS (1989) Conductometric titration of cellulose fibres. In: Schuerch C (ed) Cellulose and wood-chemistry and technology. Wiley, New York, pp 14571471

Slavik I, Kucerova M (1967) Formation of lactone bonds in cellulose during acidification and drying. Faserforsch Textiltech 18:396-397

Slavik I, Pasteka M, Kucerova M (1967) The behavior of lactone groups in cellulosic materials during the determination of carboxyl groups by different methods. Faserforsch Textiltech $18: 4-8$

Slavik I, Kucerova M (1969) Time profile of lactone and ester formation in cellulose upon acidification and drying. Faserforsch Textiltech 20:346-347

Smook GA (1990) Hornification (keyword). In: Handbook of pulp \& paper terminology. Angus Wilde, Vancouver, p 135

Stakheeva-Kaverzneva ED, Salova AS (1951) Chemical changes of cellulose macromolecule under action of oxidizing agents. IV. Lactone links in the macromolecule of oxycellulose and their effect on determination of carbonyl groups by condensation with hydroxylamine. Izvest Akad Nauk SSSR, Otdel Khim Nauk 782-790

Stakheeva-Kaverzneva ED, Salova AS (1953). Specific method of determination of carbonyl groups in oxycellulose. Zhur Anal Khim 8:365-369

Stone JE, Scallan AM (1966) Influence of drying on the pore structures of the cell wall. In: Bolam F (ed) Consolidation of the paper web. BPBMA, London, pp 145-174

Stone JE, Scallan AM (1968) A structural model for the cell wall of waterswollen wood pulp fibres based on their accessability to macromolecules. Cell Chem Technol 2:343-358

Stone JE, Scallan AM, Abrahamson B (1968) Influence of beating on cell wall swelling and internal fibrillation. Svensk Papperstidn 71:687-694

Streitwieser A, Heathcock CH (1989) Introduction to organic chemistry, 3rd edn. Macmillan, New York, p 859

Weise U (1998) Hornification-mechanisms and terminology. Paperi Puu 80:110-115

Weise U, Hiltunen LE, Paulapuro H (1998) Verhornung von Zellstoff und Maßnahmen zu ihrer Reversion. Papier 52:V14-V19 
Weise U, Paulapuro H (1996) The effect of drying and re-wetting cycles on fibre swelling. In: Proc fourth European workshop on lignocellulosics and pulp, advances in characterization and processing of wood, non-woody and secondary fibres, Stresa, Italy, 8-11 September 1996, pp 389-394

Wilson K (1966) Determination of carboxyl groups in cellulose. Svensk Papperstidn 69:386-390 Yasnovsky VM, MacDonald DM (1983) Prevention of hornification of dissolving pulp. US Patent $4,385,172$, assigned to International Paper Co 